\title{
Article \\ Seed Treatment with Iron Chlorine E6 Enhances Germination and Seedling Growth of Rice
}

\author{
Yali Xie ${ }^{1,2}$, Lihui Wei ${ }^{2}$, Yinghua $\mathrm{Ji}^{2}$ and Shuo $\mathrm{Li}^{1,2, * \mathbb{D}}$ \\ 1 School of Food and Biological Engineering, Jiangsu University, Zhenjiang 212013, China; \\ 2221918092@stmail.ujs.edu.cn \\ 2 Institute of Plant Protection, Jiangsu Academy of Agricultural Sciences, Nanjing 210014, China; \\ weilihui@jaas.ac.cn (L.W.); jiyinghua@jaas.ac.cn (Y.J.) \\ * Correspondence: lishuo@jaas.ac.cn; Tel.: +86-025-8439-0394
}

Citation: Xie, Y.; Wei, L.; Ji, Y.; Li, S. Seed Treatment with Iron Chlorine E6 Enhances Germination and Seedling Growth of Rice. Agriculture 2022, 12, 218. https://doi.org/10.3390/ agriculture12020218

Received: 22 January 2022

Accepted: 1 February 2022

Published: 2 February 2022

Publisher's Note: MDPI stays neutral with regard to jurisdictional claims in published maps and institutional affiliations.

Copyright: (C) 2022 by the authors. Licensee MDPI, Basel, Switzerland. This article is an open access article distributed under the terms and conditions of the Creative Commons Attribution (CC BY) license (https:// creativecommons.org/licenses/by/ $4.0 /)$.
Abstract: Iron chlorine e6 (ICE6), also known as iron dihydroporphine, is a new type natural plant growth regulator, which can improve some crops growth. At present, the effects of ICE6 on rice are still unclear. Therefore, it is of great significance to study the effect of ICE6 on rice growth. In this study, the effect of seed treatment with ICE6 on rice germination and seedling growth was evaluated. Rice seeds were soaked with the gradient concentration and gradient time of ICE6, respectively, and then the germination rate, growth indexes and chlorophyll content of rice were determined. The results showed seed soaking with ICE6 could improve rice seed germination, promote seedling growth and increase the chlorophyll content in plants, exhibiting a better growth promoting effect. The optimum soaking condition was 100-200 mg/L (concentration) and 24-48 h (time). The field experiment further verified the growth regulating effect of ICE6 priming on rice seedlings. After seed priming with ICE6, seed vigor became higher, and the activities of $\alpha$-amylase and protease in germinating seeds increased. The increase of seed vigor might be an important reason that ICE6 improved the germination and seedling growth. In addition, we also found ICE6 treatment could enhance the regeneration ability of seedlings. This work demonstrated the germination and growth promoting effect of ICE6 on rice, and revealed its application potential in rice production. This seed priming technique was of great promotional value in the field.

Keywords: Iron chlorine e6; seed treatment; rice; germination; growth promoting effect

\section{Introduction}

Rice is an important cereal staple food for a large part of the world population, nearly half of people in the world live on rice, and its yield and quality influence its marketability and the health of people's life [1]. Rice production in Asia accounts for $91 \%$ of the world, and rice exports in Asia accounts for $70 \%$ of the world [2]. The safe production of rice plays a very important role in ensuring world food security. It can be seen that the food problem is related to the national economy and people's livelihood [3], therefore, the safety production of rice is of great significance.

The current challenge for agriculture is to meet the growing demand for sustainable food production and ensure high quality nutrition for the rapidly growing population. Therefore, it is necessary to increase the yield per unit area of cultivated land and ensure the full progress of grain production. Exploiting plant growth regulators (PGRs) is an avenue to achieve this goal [4]. PGRs are a class of chemicals with a similar function as natural plant exogenous hormones, which affect the plants' physiological and biochemical processes even at extremely low concentrations [4-6]. PGRs can modify plant growth and development factors that regulate numerous developmental or metabolic processes, including seeds germination, vegetative growth, flowering, fruit formation, defoliation, etc. $[7,8]$. Based on their different physiological functions, PGRs are mainly categorized 
into three groups: plant growth promoters (auxins, gibberellins, cytokinins, etc.), growth inhibitors (abscisic acid, methyljasmonate, etc.) and growth retardant (paclobutrazol, chlormequat chloride, etc.) [9]. Besides the classical phytohormones and synthetic PGRs, many plant metabolites have been reported to affect plant germination and development, which may act as leading compounds to develop novel PGRs [10-12]. In agricultural production, PGRs are mainly used in crops to regulate their growth and development and improve the yield and quality. The main mechanism of PGRs is the modification of the crop by altering its response rate or pattern to external and internal factors that regulate development from germination to maturity, as well as postharvest ripening [13]. After entering plant cells, similar to endogenous hormones, PGRs bind receptors through specific affinity interaction. Some receptors are located in the plasma membrane, after binding with indoleacetic acid, they change the proton pump activity on the plasma membrane and affect the membrane permeability [4,7]. Some receptors in cytoplasm and nucleus can affect the synthesis of DNA/RNA and protein after binding with PGRs, and then regulate the special metabolic enzymes [4,7].

In order to improve the yield and quality of rice, it is necessary to study the application of PGRs in rice plants. Iron chlorine e6 (ICE6, CAS No. 19660-77-6), also known as iron dihydroporphine (Figure 1), is a new type natural PGR, which was composed of ferric ions chelated by chlorin e6. ICE6 was originally extracted from traditional Chinese medicine Faeces Bombycis, and it can inhibit chlorophyll enzyme and delay chlorophyll degradation to enhance photosynthesis. Wang et al. [14] firstly reported that ICE6 could promote the growth of wheat without adverse effects on the quality of crops, so the increasing effect of yield and income was significant. At present, the effect evaluation of ICE6 field application in rape, grape and tobacco has also been evaluated, and ICE6 exhibited a good effect on promoting crop growth and increasing production $[15,16]$.

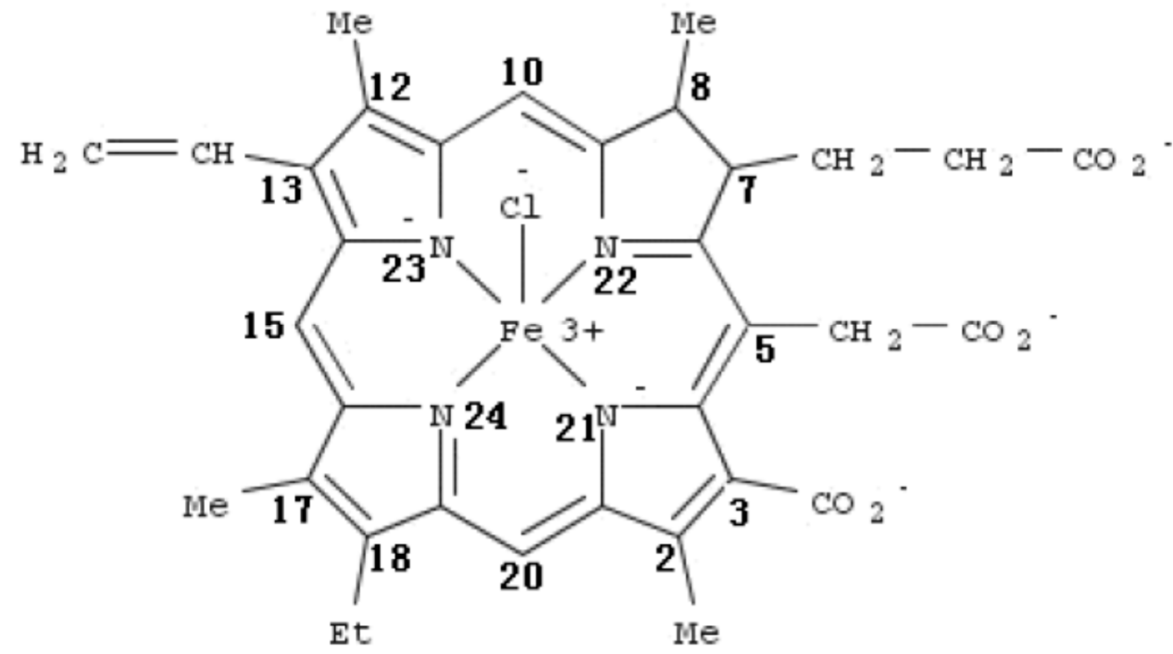

Figure 1. Structure of iron chlorine e6 (ICE6).

At present, PGRs have been included in pesticide supervision in most countries. Different kinds of PGRs are used in different ways. Generally, in agricultural production, there are mainly the following methods: seed coating, seed dressing, seed soaking, foliar spraying, drip method, soil irrigation and fumigation. In the early stage of crop growth, seed treatment with appropriate PGRs or some special compounds can improve germination and growth, and enhance the tolerance of plants to pathogens and abiotic stresses. Seed soaking is a simple and effective farming method. It was reported that seed priming with nano- $\mathrm{Fe}_{2} \mathrm{O}_{3}$ at 10 and 50-100 $\mathrm{mg} / \mathrm{L}$, respectively, exhibited the best effect on improving seed germination and seedling growth [17]. Seed soaking with gibberellic acid and N6benzyladenine could enhance substantially dry matter of floral buds and reduce abscission rate [18]. Hou et al. [19] found that seed soaking with 6-Benzylaminopurine (0.5 mg/L) exhibited a better effect on improving seed germination of Bupleurum chinensis. 
As a new type PGR, ICE6 can improve some crops growth and, to our knowledge, no information is available about the impacts of seed priming with ICE6 on rice seed germination and seedling physiology under normal conditions. Thus, the present investigation aimed to comprehensively evaluate the potential of seed treatment with ICE6 in improving rice seed germination and seedling growth.

\section{Materials and Methods}

\subsection{Biological Material}

Seeds of rice (cultivar Wuyujing No.3) were preserved by author's laboratory for indoor experiment. In the field experiment, rice seeds (cultivar Lindao No.16) were provided by Huanghai farm in Xiangshui, Jiangsu. The ICE6 soluble preparation was produced and provided by Nanjing Bostec Bioengineering Co., Ltd. Each gram of the preparation powder contained $0.2 \mathrm{mg}(0.02 \%)$ of ICE6 active ingredient, with $\beta$-cyclodextrin $(\beta-C D)$ as the solubilizer.

\subsection{Effects of Soaking Seeds with ICE6 on Seed Germination and Seedling Growth}

To screen the most suitable parameters for seed soaking with ICE6, the treatment of soaking seeds with ICE6 at different concentration was carried out. Through a preexperiment, it was found that ICE6 could improve germination and seedling growth as long as the seed soaking time was more than $6 \mathrm{~h}$. Rice seeds were soaked for $6 \mathrm{~h}$ with a gradient concentration ICE6 preparation solution (2500, 1000, 500, 200, 100, 40 and $16 \mathrm{mg} / \mathrm{L})$ and water (control). Seeds were washed to remove ICE6 on the surface, and then soaked in water for $48 \mathrm{~h}$ before sown in $0.3 \mathrm{~L}$ plastic pots containing soil substrate. After 3 days of sowing, the germination rate (the percentage of germination seed number in the total number of test seeds) was counted. After 12 days, the growth morphological indexes of rice seedlings were measured, including root length, root number, root fresh weight, plant height and leaf fresh weight. Both seed germination and seedling growth were at $26{ }^{\circ} \mathrm{C}$ with a photoperiod of $14 \mathrm{~h} / 10 \mathrm{~h}$ (light/dark) in a light incubator. Besides, chlorophyll content in seedling leaves was determined using the acetone extraction method [20]. After the optimal concentration was determined, seed treatment with ICE6 at different soaking time was also performed. Seeds were soaked in ICE6 preparation $(100 \mathrm{mg} / \mathrm{L})$ for a gradient time $(0.75,1.5,3,6,12,24$ and $48 \mathrm{~h})$. After ICE6 priming, seeds were washed with water and then continued to soak in water to make up the total soaking time (ICE6 and water) of each treatment to $48 \mathrm{~h}$ before sowing, with seeds soaked in water for $48 \mathrm{~h}$ as control. The germination rate, growth indexes and chlorophyll content of rice were determined, as described above. Six independent replicates were set in each treatment, with 30 seedlings per replication. To exclude the influence of solubilizer on the results, seeds were also primed with solubilizer $\beta$-CD at a certain concentration $(100 \mathrm{mg} / \mathrm{L})$ and time $(24 \mathrm{~h})$, respectively, and the relevant indexes were tested.

\subsection{Effect of Soaking Seeds with ICE6 on Seed Vigor during Germination}

In order to explain the reason why ICE6 improves seed germination and seedling growth, seed viability and the activities of $\alpha$-amylase and protease in germinating seeds were detected. Seeds were soaked in ICE6 preparation (100 and $200 \mathrm{mg} / \mathrm{L}$ ), solubilizer and water for $48 \mathrm{~h}$, respectively. After 2 days, when the seeds were just budding, seeds were collected and homogenized in water to produce crude enzyme extract. The seed viability was assessed using quantitative 2,3,5-triphenyltetrazolium chloride (TTC) assay [21]. The content of triphenyl tetrazolium formazan (TTF) produced by dehydrogenase per gram of seed in $1 \mathrm{~h}$ was used as seed vigor index. The $\alpha$-amylase activity was tested by the 3,5-dinitrosalicylic acid method [22]. For detection of $\alpha$-amylase activity, enzyme extract was placed at $70{ }^{\circ} \mathrm{C}$ for $15 \mathrm{~min}$ to inactivate $\beta$-amylase before determination. Under the condition of $40{ }^{\circ} \mathrm{C}$ and $\mathrm{pH} 5.6$, the amount of enzyme that hydrolyze and produce $1 \mathrm{mg}$ reducing sugar from $1 \%$ soluble starch solution per minute was defined as one activity unit (U). The activity of protease was determined according to the method by Harvey and 
Oaks [23]. The amount of enzyme hydrolyzing $1 \%$ casein solution to produce $1 \mu \mathrm{g}$ tyrosine at $40{ }^{\circ} \mathrm{C}$ and pH7.0 in $1 \mathrm{~min}$ was as one activity unit (U). In all experiments, three replicates were set in each treatment.

\subsection{Analysis of Seedling Regeneration Ability after ICE6 Treatment}

Seeds were soaked in ICE6 preparation $(100 \mathrm{mg} / \mathrm{L}), \beta-\mathrm{CD}(100 \mathrm{mg} / \mathrm{L})$ and water, respectively, for $48 \mathrm{~h}$ before sowing. When the rice buds grew to about $2 \mathrm{~cm}$ in length, the whole buds were cut off from the base. Then, the treated seedlings without buds continued to grow for 5 days at $26^{\circ} \mathrm{C}$, and plant height of seedlings was measured and photographed. Three replicates were set in each treatment.

\subsection{The Field Efficacy Evaluation of ICE6 on Rice}

In order to further evaluate the application potential of ICE6, a field experiment of seed treatment with ICE6 was performed in Huanghai Farm in Xiangshui, Jiangsu. Rice seeds (cultivar Lindao No.16) were soaked in ICE6 solution (200 mg/L) for $24 \mathrm{~h}$ in late May 2021, and seeds soaked with water were as control. After draining the water, seeds were sown in the seedling tray containing soil. After 15 days, the growth indexes and chlorophyll content of seedlings were tested. Three independent replicates were set in each treatment, with 30 seedlings per replication.

\subsection{Statistical Analysis}

All data were expressed as the mean \pm SD. Statistically significant differences between the experimental and control groups were determined with the one-way ANOVA (Tukey's test) using the statistical analysis system (Version 8.0, SAS Institute, Cary, NC, USA). $p<0.05$ was considered statistically significant.

\section{Results}

\subsection{Seed Soaking with ICE6 Improved the Germination}

After soaking seeds with a gradient concentration ICE6 for $6 \mathrm{~h}$, the germination rates of rice seeds in different treatments were different. When the concentrations were $100(0.01 \%)$ and $200(0.02 \%) \mathrm{mg} / \mathrm{L}$, the germination rates were significantly higher than control treatment (Figure 2a). In addition, the germination was inhibited at a high ICE6 concentration $(2500 \mathrm{mg} / \mathrm{L})$. The seeds were soaked with $100 \mathrm{mg} / \mathrm{L}$ ICE6 for a gradient time, and the effects of different soaking time on germination were analyzed. When the soaking time was more than $1.5 \mathrm{~h}$, the germination rate of each treatment was higher than that of the control group, but there was no significant difference among different treatments (1.5-48 h) (Figure $2 \mathrm{~b}$ ). The results indicated that seed soaking with appropriate concentration (100-200 mg/L) ICE6 could improve rice seed germination.

(a)

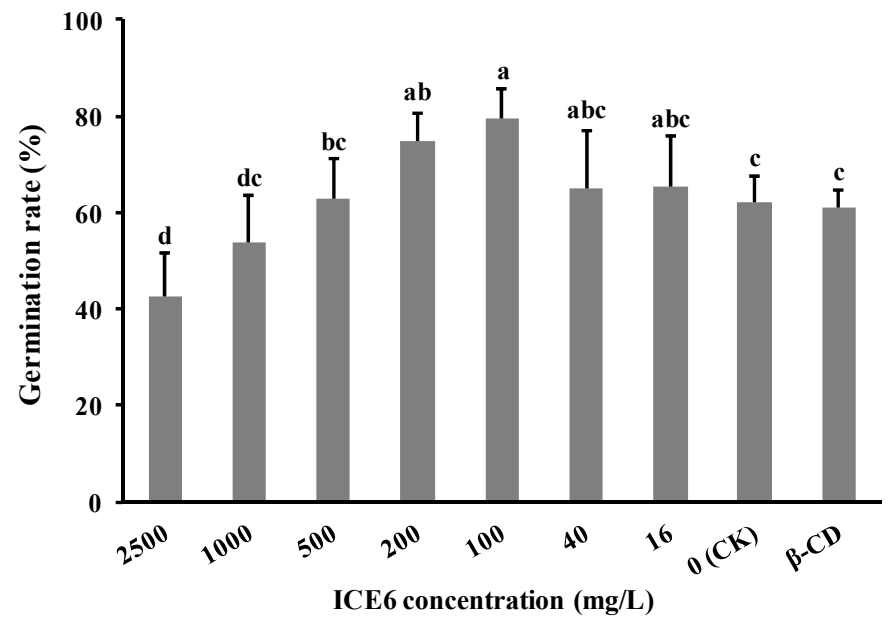

Figure 2. Cont. 


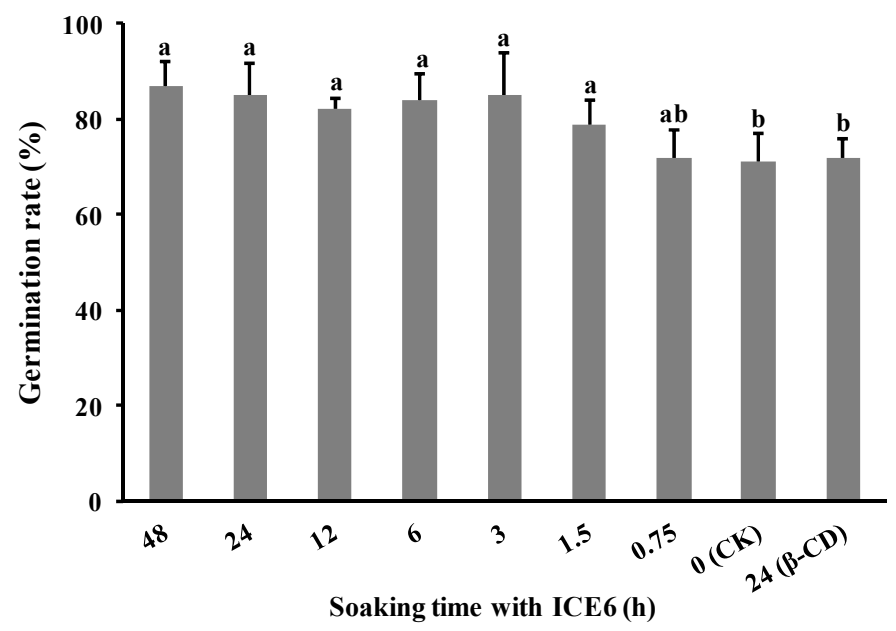

Figure 2. Effect of soaking seeds in ICE6 on rice germination rate. (a) Soaking seeds with a gradient concentration ICE6 for $6 \mathrm{~h}$; and (b) soaking seeds in ICE6 (100 mg/L) for different time. Water (CK) and $\beta-C D$ treatment are used as control. Date is shown as the mean $( \pm S D)$, and the different letters above the error bars indicate statistically significant difference by Tukey's test $(p<0.05)$.

\subsection{Seed Soaking with ICE6 Promoted Growth of Rice Seedlings}

Seeds were soaked with a gradient concentration ICE6 or a gradient time before sowing. After 12 days, the growth indexes were tested. Compared with the control, there was no significant change in the root number of each ICE6 treatment group. When concentration was $100 \mathrm{mg} / \mathrm{L}$, the root fresh weight of seedlings was significantly higher than that of the control and other treatment groups (Table 1), reflecting the role of ICE6 in promoting root growth. At some concentration, the root length of seedlings became short. In addition, the plant height and leaf fresh weight of seedlings in $2500 \mathrm{mg} / \mathrm{L}$ ICE6 treatment group were higher than other treatment groups. In the results of gradient soaking time (Table 2), there was no significant change in the root number between the control and each time treatment group. Notably, as the soaking time is extended to more than $24 \mathrm{~h}$, the root weight, root length, plant height and leaf weight of seedlings were significantly higher than the control group. These results suggested that seed soaking with ICE6 could promote seedling growth, under the optimum soaking concentration (100-200 $\mathrm{mg} / \mathrm{L})$ and time (24-48 h).

Table 1. Effect of soaking seeds with a gradient concentration ICE6 on rice seedling growth.

\begin{tabular}{ccccccc}
\hline $\begin{array}{c}\text { Concentration of } \\
\text { ICE6 Preparation } \\
\text { (mg/L) }\end{array}$ & $\begin{array}{c}\text { Concentration of } \\
\text { ICE6 Active } \\
\text { Ingredient } \\
\text { (mg/L) }\end{array}$ & Numbers of Root & $\begin{array}{l}\text { Root Fresh } \\
\text { Weight (g) }\end{array}$ & Root Length (cm) & $\begin{array}{c}\text { Plant Height } \\
\text { (cm) }\end{array}$ & $\begin{array}{c}\text { Leaf Fresh } \\
\text { Weight (g) }\end{array}$ \\
\hline 2500 & 0.5 & $5.15 \pm 1.12 \mathrm{a}$ & $0.042 \pm 0.010 \mathrm{~b}$ & $10.17 \pm 1.44 \mathrm{ab}$ & $17.32 \pm 1.66 \mathrm{a}$ & $0.067 \pm 0.013 \mathrm{a}$ \\
1000 & 0.2 & $4.95 \pm 1.01 \mathrm{abc}$ & $0.048 \pm 0.011 \mathrm{~b}$ & $9.14 \pm 1.81 \mathrm{~b}$ & $14.87 \pm 1.28 \mathrm{bcd}$ & $0.057 \pm 0.014 \mathrm{~b}$ \\
500 & 0.1 & $4.85 \pm 1.27 \mathrm{abc}$ & $0.040 \pm 0.013 \mathrm{~b}$ & $9.02 \pm 1.73 \mathrm{~b}$ & $14.77 \pm 1.30 \mathrm{~cd}$ & $0.057 \pm 0.013 \mathrm{~b}$ \\
200 & 0.04 & $5.03 \pm 1.03 \mathrm{ab}$ & $0.046 \pm 0.014 \mathrm{~b}$ & $10.00 \pm 1.48 \mathrm{ab}$ & $14.98 \pm 1.26 \mathrm{bcd}$ & $0.055 \pm 0.011 \mathrm{~b}$ \\
100 & 0.02 & $5.08 \pm 1.02 \mathrm{ab}$ & $0.057 \pm 0.016 \mathrm{a}$ & $10.59 \pm 1.89 \mathrm{a}$ & $15.81 \pm 1.37 \mathrm{~b}$ & $0.060 \pm 0.011 \mathrm{ab}$ \\
40 & 0.008 & $4.4 \pm 1.08 \mathrm{bc}$ & $0.041 \pm 0.011 \mathrm{~b}$ & $9.29 \pm 1.42 \mathrm{~b}$ & $14.11 \pm 1.39 \mathrm{~d}$ & $0.056 \pm 0.011 \mathrm{~b}$ \\
16 & 0.0032 & $4.23 \pm 1.10 \mathrm{c}$ & $0.041 \pm 0.011 \mathrm{~b}$ & $10.05 \pm 1.86 \mathrm{ab}$ & $15.25 \pm 1.83 \mathrm{bc}$ & $0.056 \pm 0.013 \mathrm{~b}$ \\
$0(\mathrm{CK})$ & 0 & $4.78 \pm 1.10 \mathrm{abc}$ & $0.047 \pm 0.014 \mathrm{~b}$ & $11.03 \pm 2.37 \mathrm{a}$ & $14.88 \pm 1.47 \mathrm{bcd}$ & $0.054 \pm 0.013 \mathrm{~b}$ \\
$\beta-\mathrm{CD}$ & 0 & $4.80 \pm 1.03 \mathrm{abc}$ & $0.045 \pm 0.009 \mathrm{~b}$ & $8.69 \pm 1.70 \mathrm{~b}$ & $13.84 \pm 1.78 \mathrm{~d}$ & $0.050 \pm 0.015 \mathrm{~b}$ \\
\hline
\end{tabular}

Water $(\mathrm{CK})$ and $\beta-C D$ treatment are used as control. Date are shown as the mean $( \pm \mathrm{SD})$, and the different letters following mean \pm SD indicate statistically significant difference by Tukey's test $(p<0.05)$. 
Table 2. Effect of soaking seeds with ICE6 for different time on rice seedling growth.

\begin{tabular}{cccccc}
\hline Time (h) & $\begin{array}{c}\text { Numbers of } \\
\text { Root }\end{array}$ & $\begin{array}{c}\text { Root Fresh } \\
\text { Weight } \mathbf{( g )}\end{array}$ & $\begin{array}{c}\text { Root Length } \\
\mathbf{( c m})\end{array}$ & $\begin{array}{c}\text { Plant Height } \\
\mathbf{( c m})\end{array}$ & $\begin{array}{c}\text { Leaf Fresh } \\
\text { Weight } \mathbf{( g )}\end{array}$ \\
\hline 48 & $4.75 \pm 0.98 \mathrm{a}$ & $0.084 \pm 0.020 \mathrm{a}$ & $13.56 \pm 1.28 \mathrm{a}$ & $17.04 \pm 2.16 \mathrm{a}$ & $0.062 \pm 0.012 \mathrm{a}$ \\
24 & $4.50 \pm 0.79 \mathrm{a}$ & $0.085 \pm 0.019 \mathrm{a}$ & $12.54 \pm 1.63 \mathrm{abc}$ & $17.23 \pm 1.79 \mathrm{a}$ & $0.062 \pm 0.012 \mathrm{a}$ \\
12 & $4.55 \pm 1.22 \mathrm{a}$ & $0.079 \pm 0.014 \mathrm{ab}$ & $11.60 \pm 1.52 \mathrm{cde}$ & $16.61 \pm 1.92 \mathrm{ab}$ & $0.057 \pm 0.014 \mathrm{ab}$ \\
6 & $4.68 \pm 1.00 \mathrm{a}$ & $0.081 \pm 0.015 \mathrm{ab}$ & $12.36 \pm 1.68 \mathrm{bc}$ & $15.49 \pm 1.58 \mathrm{~b}$ & $0.057 \pm 0.012 \mathrm{ab}$ \\
3 & $4.88 \pm 0.79 \mathrm{a}$ & $0.081 \pm 0.013 \mathrm{ab}$ & $12.10 \pm 1.54 \mathrm{bcd}$ & $16.49 \pm 1.72 \mathrm{ab}$ & $0.058 \pm 0.011 \mathrm{ab}$ \\
1.5 & $4.70 \pm 1.04 \mathrm{a}$ & $0.079 \pm 0.014 \mathrm{ab}$ & $11.04 \pm 1.32 \mathrm{de}$ & $16.74 \pm 1.80 \mathrm{ab}$ & $0.056 \pm 0.013 \mathrm{ab}$ \\
0.75 & $4.78 \pm 1.07 \mathrm{a}$ & $0.073 \pm 0.014 \mathrm{~b}$ & $10.78 \pm 1.69 \mathrm{e}$ & $16.68 \pm 1.79 \mathrm{ab}$ & $0.057 \pm 0.012 \mathrm{ab}$ \\
$0(\mathrm{CK})$ & $5.05 \pm 1.06 \mathrm{a}$ & $0.076 \pm 0.016 \mathrm{~b}$ & $13.00 \pm 2.15 \mathrm{ab}$ & $15.48 \pm 1.16 \mathrm{~b}$ & $0.053 \pm 0.010 \mathrm{~b}$ \\
$24(\beta-\mathrm{CD})$ & $4.80 \pm 0.99 \mathrm{a}$ & $0.072 \pm 0.015 \mathrm{~b}$ & $9.11 \pm 2.01 \mathrm{e}$ & $13.79 \pm 1.77 \mathrm{c}$ & $0.044 \pm 0.015 \mathrm{c}$ \\
\hline
\end{tabular}

The concentration of ICE6 is $100 \mathrm{mg} / \mathrm{L}$, and water (CK) and $\beta$-CD treatment are used as control. Date are shown as the mean $( \pm \mathrm{SD})$, and the different letters following mean $\pm \mathrm{SD}$ indicate statistically significant difference by Tukey's test $(p<0.05)$.

\subsection{Seed Soaking with ICE6 Increased the Chlorophyll Content of Rice Seedlings}

In higher plants, chlorophyll mainly includes chlorophyll a and b, which are important pigments involved in the photosynthesis. The content of chlorophyll is an important indicator to assess the photosynthesis intensity of plants. After rice seeds were treated by ICE6 with gradient concentration and time, when seedlings grew to $15 \mathrm{~cm}$, the content of chlorophyll was determined. When ICE6 were 100 and $200 \mathrm{mg} / \mathrm{L}$, the chlorophyll content of seedlings was significantly higher than other treatments (Figure 3a), and the chlorophyll of plants at 6,12, 24 and $48 \mathrm{~h}$ soaking groups was significantly higher than the control group (Figure 3b), indicating that seed priming with ICE6 could increase the chlorophyll content of rice plants.

(a)
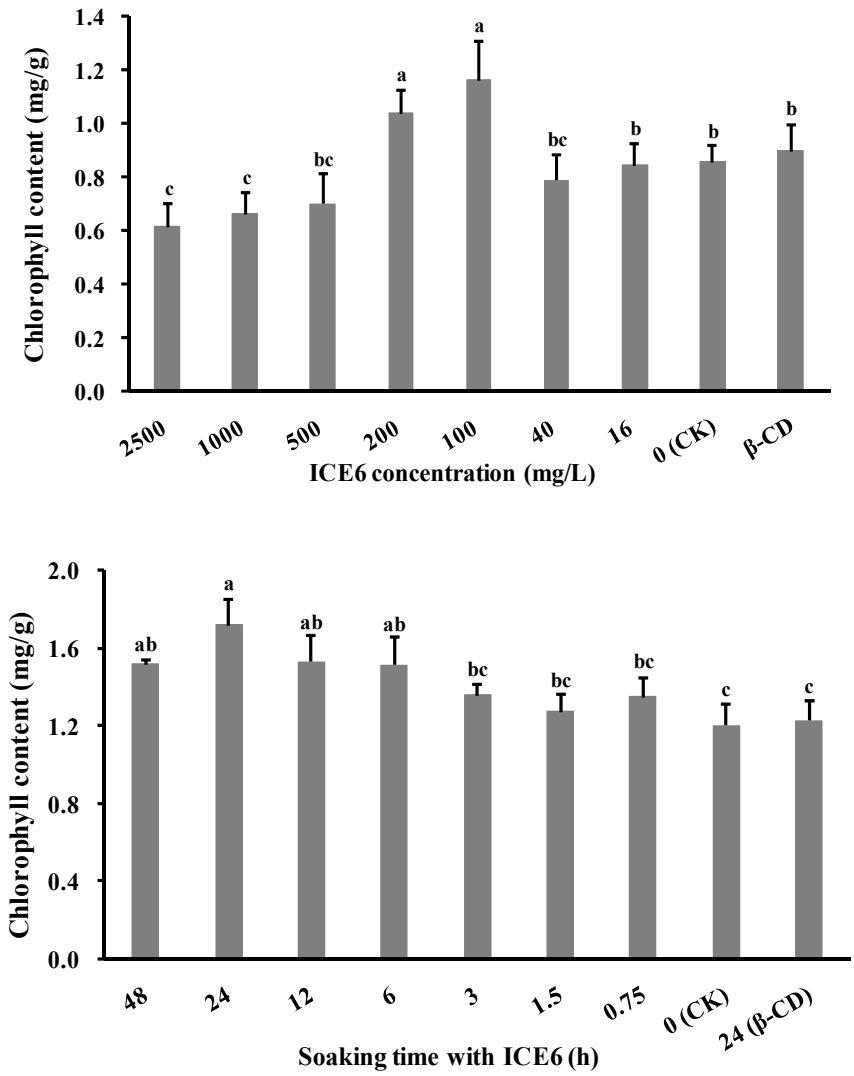

Figure 3. The chlorophyll content of rice seedlings after seed treatment with ICE6. (a) Seed treatment with a gradient concentration ICE6 for $6 \mathrm{~h}$; and (b) seed treatment with ICE6 (100 mg/L) for different time. Water $(\mathrm{CK})$ and $\beta-\mathrm{CD}(100 \mathrm{mg} / \mathrm{L})$ treatment are used as control. Date are shown as the mean $( \pm \mathrm{SD})$, and the different letters above the error bars indicate statistically significant difference by Tukey's test $(p<0.05)$. 


\subsection{The Seed Vigor Was Improved by Soaking with ICE6}

Seed vigor is an important comprehensive index to reflect the quality of seeds, and it is a characteristic of high germination rate [24]. The TTF content in seeds is positively correlated to germination rate [21], which was used as the seed vigor index. In the standard curve, TTF content $(0.05-1 \mathrm{mg})$ had a linear relationship with absorbance at $485 \mathrm{~nm}$ $\left(y=0.58326 x+0.00066, R^{2}=0.9996\right)$. TTF content in rice seeds treated by ICE6 was determined, and the result showed that the production of TTF increased significantly in 100 $\mathrm{mg} / \mathrm{L}$ treatment group compared to other groups (Figure $4 \mathrm{a}$ ), indicating that seed vigor was improved by ICE6 with appropriate concentration. The activities of $\alpha$-amylase and protease can also reflect seed germination vigor to a certain extent, and these indicators in germinating seeds soaked by ICE6 were tested. It was found that $\alpha$-amylase activity of seeds after soaking with ICE6 was significantly higher than control groups, in which the $100 \mathrm{mg} / \mathrm{L}$ treatment group $(0.296 \mathrm{U} / \mathrm{g})$ was higher than $200 \mathrm{mg} / \mathrm{L}$ treatment $(0.251 \mathrm{U} / \mathrm{g})$ (Figure $4 \mathrm{~b}$ ). In addition, protease activity of germinating seeds also increased via ICE6 treatment (Figure 4c). These results suggested ICE6 priming seed could enhance the activities of $\alpha$-amylase and protease, which caused an increase in seed vigor. It might be an important reason that ICE6 improved the germination and seedling growth.

(a)

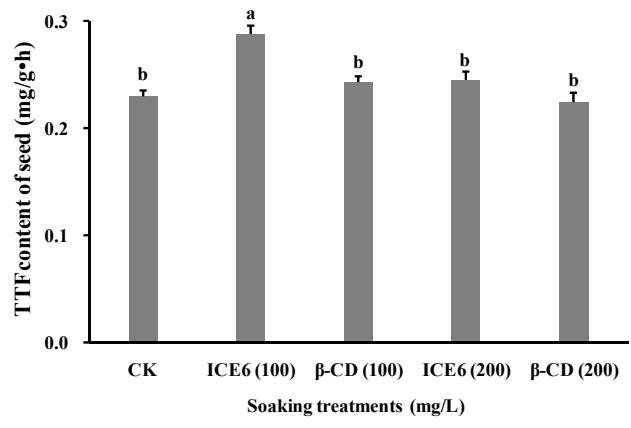

(b)

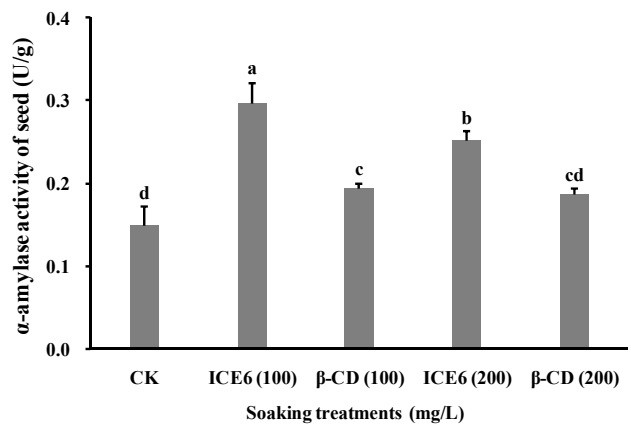

(c)

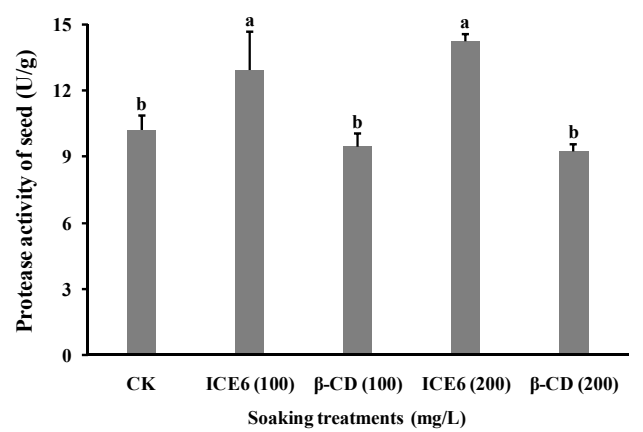

Figure 4. Effect of soaking rice seeds with ICE6 on seed vigor (a), $\alpha$-amylase activity (b) and protease activity (c) during germination. Water $(\mathrm{CK})$ and $\beta-\mathrm{CD}$ treatment are used as control. Date are shown as the mean $( \pm S D)$, and the different letters above the error bars indicate statistically significant difference by Tukey's test $(p<0.05)$. 


\subsection{ICE6 Enhanced the Regeneration of Rice Seedlings}

Plant regeneration is essential for survival upon wounding and is, hence, considered to be a strong natural selective trait [25]. In analysis of regeneration ability of ICE6 on seedlings, the $2 \mathrm{~cm}$ length rice buds were cut off to observe growth. After 5 days of injury, the height and growth status of seedlings in the treatment group were significantly better than the control (Figure 5), in which the status of seedlings from $100 \mathrm{mg} / \mathrm{L}$ treatment was the best (Figure 6), suggesting ICE6 treatment could enhance the regeneration ability of seedlings. At the same time, it was also a side proof of the growth promoting effect of ICE6.

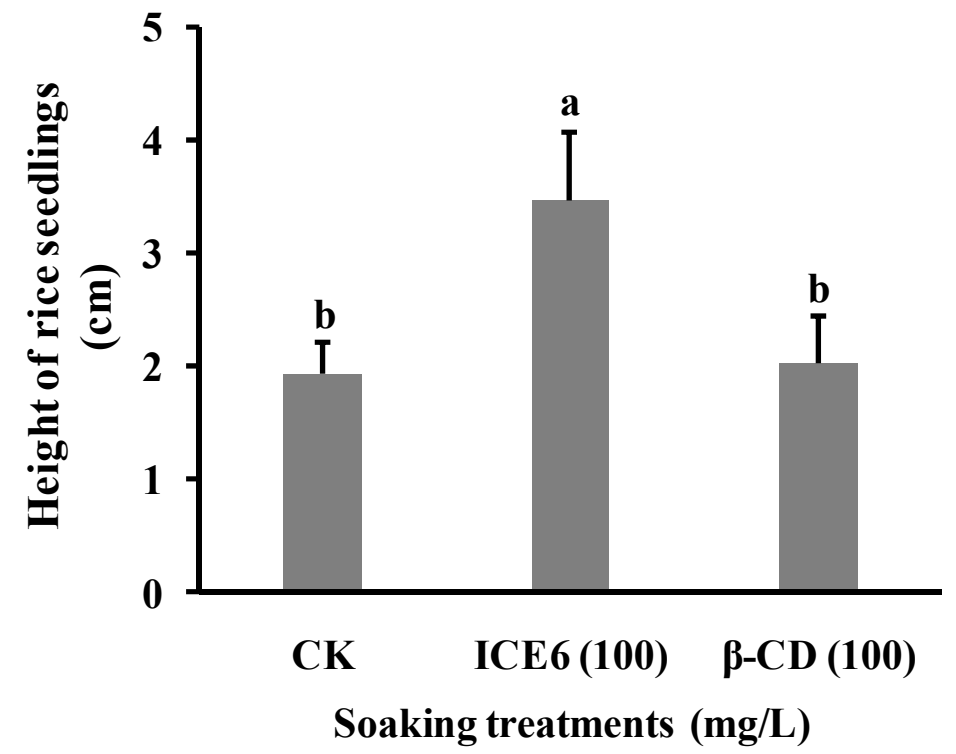

Figure 5. The regeneration ability of rice seedlings after ICE6 treatment. Height of seedlings was exhibited after 5 days of bud cutting. Water (CK) and $\beta-C D$ treatment are used as control. Date are shown as the mean $( \pm \mathrm{SD})$, and the different letters above the error bars indicate statistically significant difference by Tukey's test $(p<0.05)$.
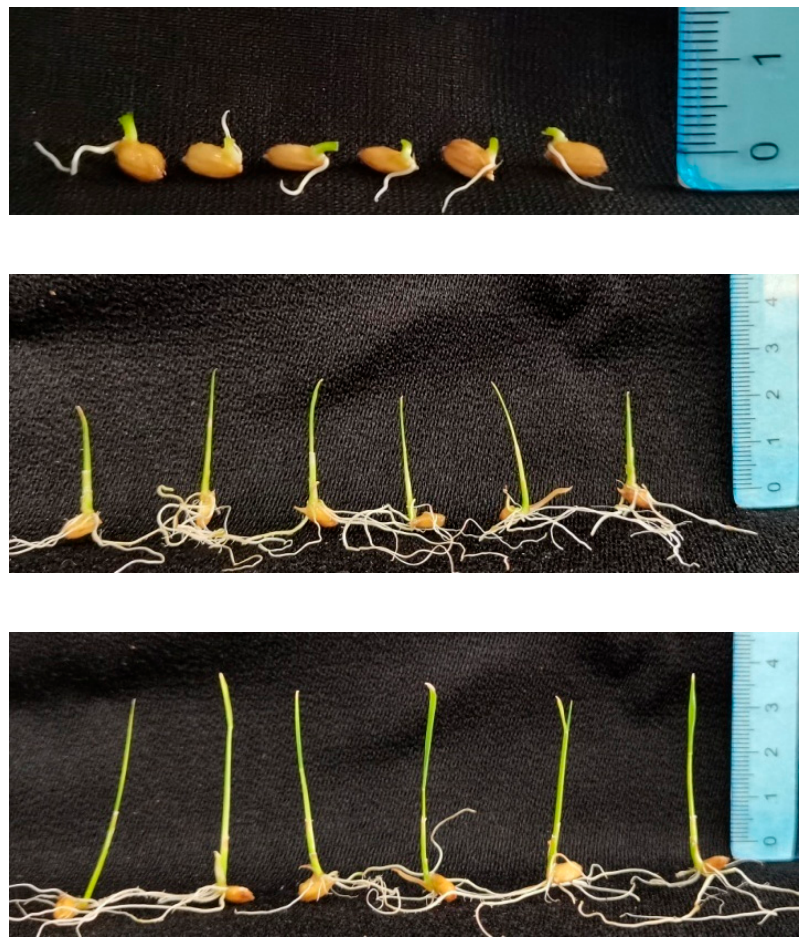

Figure 6. Cont.

\section{Seeds with injured buds}

\section{Seedlings in CK group after 5} days

\section{Seedlings in ICE6 treatment group after 5 days}




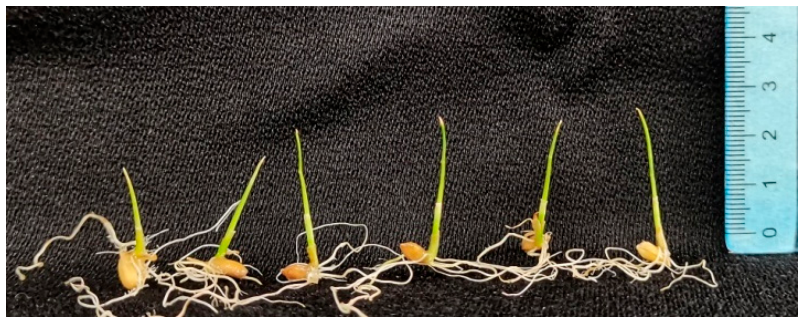

\section{Seedlings in $\beta$-CD treatment group after 5 days}

Figure 6. Recovery and growth status of rice seedlings with different treatment after 5 days of bud cutting. The unit of dividing rule in the figure is centimeter, and different treatments are indicated on the right.

\subsection{Effects of ICE6 Priming on Rice Seedling Growth under Field Conditions}

The field experiment of ICE6 priming rice seed was performed in Huanghai Farm in Xiangshui, Jiangsu. After 15 days of sowing, the growth indexes of seedlings were tested. Compared with the control, the root length of seedlings was shorter, but the root weight increased significantly after ICE6 treatment (Table 3), suggesting the roots of seedlings became thicker and more developed (Figure 7). In ICE6 treatment group, plant height decreased and chlorophyll content increased, and there was no significant change in leaf fresh weight between ICE6 treatment and control (Table 3), which indicated that ICE6 priming caused seedlings short and strong with enhanced photosynthesis. In general, ICE6 played a good role in regulating rice seedling growth in the field.

Table 3. Effect of soaking seeds with ICE6 on rice seedling growth under field conditions.

\begin{tabular}{ccc}
\hline Growth Indexes & ICE6 Treatment $(\mathbf{2 0 0} \mathbf{~ m g} / \mathbf{L})$ & Water Treatment (CK) \\
\hline Root fresh weight $(\mathrm{g})$ & $0.17 \pm 0.033 \mathrm{a}$ & $0.13 \pm 0.039 \mathrm{~b}$ \\
Root length $(\mathrm{cm})$ & $6.93 \pm 1.32 \mathrm{~b}$ & $7.66 \pm 1.45 \mathrm{a}$ \\
Plant height $(\mathrm{cm})$ & $10.42 \pm 1.28 \mathrm{~b}$ & $12.41 \pm 1.15 \mathrm{a}$ \\
Leaf fresh weight $(\mathrm{g})$ & $0.089 \pm 0.025 \mathrm{a}$ & $0.10 \pm 0.028 \mathrm{a}$ \\
Chlorophyll content $(\mathrm{mg} / \mathrm{g})$ & $1.25 \pm 0.24 \mathrm{a}$ & $0.92 \pm 0.12 \mathrm{~b}$ \\
\hline
\end{tabular}

The concentration of ICE6 is $200 \mathrm{mg} / \mathrm{L}$, and water treatment (CK) is used as control. Date are shown as the mean $( \pm \mathrm{SD})$, and the different letters following mean \pm SD indicate statistically significant difference by Tukey's test $(p<0.05)$.

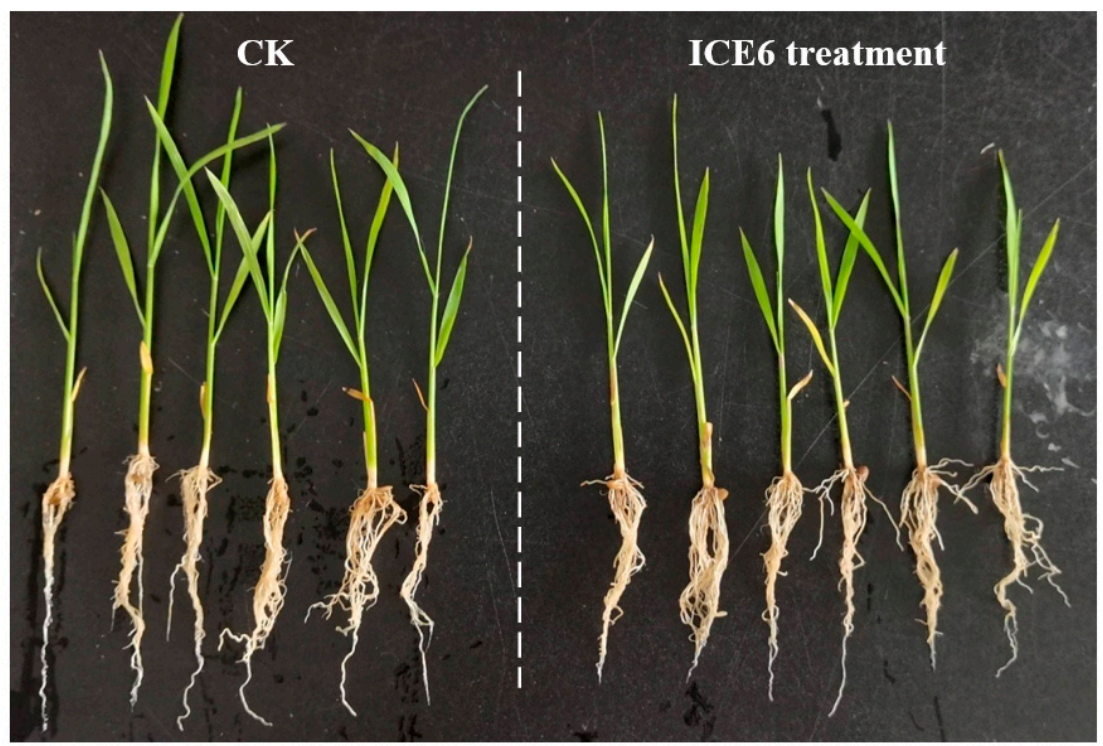

Figure 7. The growth status of rice seedlings after ICE6 treatment in the field experiment. 


\section{Discussion}

Seed germination is the most important and primary stage in plant growth cycle, and its success depends on various regulatory factors, especially the seed germination is strongly affected by environmental signals (such as temperature, light, water supply and oxygen) and seed dormancy [26,27]. The successful germination of seeds means that plants have passed the most critical stage of their life cycle, which is crucial for crop yield and plant survival in natural ecosystems [28]. The growth and development of rice begins with the germination process of seeds. Therefore, it is of great significance to evaluate the effect of the new plant regulator ICE6 on the germination and seedling growth of rice for promoting rice production.

The success of seed initiation is closely related to plant genotype, physiology, seed vigor and adopted initiation method [29]. Seed soaking is a simple and economical method to improve seed germination and promote growth. It was shown that the germination rate of tomato, bermuda grass and cucumber seeds soaked with polyethylene glycol increased in salt environment, while spinach seeds treated with the same treatment exhibited strong cold resistance and heat resistance [30]. Seed priming with selenium and salicylic acid significantly promoted the emergence and growth of rice seedlings, and the amylase activity, soluble sugar content and respiration rate of rice seedlings were higher [31]. In this study, the effect of ICE6 preparation on rice seed germination and seedling growth was evaluated, and it was found that seed soaking with appropriate concentration ICE6 could improve seed germination, promote root growth of seedlings, and increase the chlorophyll content in seedlings. By comparing the comprehensive indicators of plants from different treatments, the optimum seed soaking condition was confirmed, which was a concentration of $100-200 \mathrm{mg} / \mathrm{L}$ and a time of $24-48 \mathrm{~h}$. In a subsequent field experiment, seed treatment with the condition of $200 \mathrm{mg} / \mathrm{L}$ and $24 \mathrm{~h}$ caused seedlings short and strong with enhanced photosynthesis, which is very suitable for machine transplanting. Comparing the results of indoor and field experiments, the similarities were that root fresh weight and chlorophyll content of plants increased after ICE6 treatment, which is conducive to plant growth. The difference was that under indoor condition, the plant height in ICE6 treatment $(100 \mathrm{mg} / \mathrm{L}$, $24 \mathrm{~h}$ ) group was higher than control, while in the field experiment, the plant height in the ICE6 treatment $(200 \mathrm{mg} / \mathrm{L}, 24 \mathrm{~h})$ group became short. Although the concentration was different, it might not be the main reason. It was considered that the reason for the different results might be the inconsistent measurement time. In the indoor experiment, the plant height of the control was $15.48 \mathrm{~cm}$ at the time of measurement, while in the field experiment, the measurement time was earlier, and the plant height in the control was $12.41 \mathrm{~cm}$. ICE6 might inhibit the growth of rice seedlings in the early stage and promote the growth in the later stage. This phenomenon was also observed in the field experiment, in which the early seedlings were short, but the rice treated with ICE6 grew higher and better after machine transplanting. These results provided reliable technical parameters for ICE6 future application in rice production.

Germination rate is one of the most important indexes of conventional seed quality [26]. Our results showed that the germination rate of rice seeds was improved by ICE6, and seed vigor index was also increased by ICE6. Seed germination vigor is driven by the ability of plant embryos in seeds to recover their metabolic activities in a coordinated and orderly manner, and it is also an important indicator of seed quality, which determines the potential of rapid and uniform emergence of plants [32,33]. During germination, the $\alpha$-amylase and protease of seed play important roles in hydrolysis of stored nutrients to support the growth of young embryo, and their activities are closely related to seed germination vigor $[34,35]$. After ICE6 treatment, the activities of $\alpha$-amylase and protease increased in seeds, which suggested that these hydrolases were activated rapidly and efficiently to hydrolyze stored nutrients in the endosperm for supplying young embryo after absorbing ICE6. It was demonstrated that the high vigor seeds had stronger stress resistance, faster seedling formation, vigorous seedling growth, high yield and quality in 
field [24]. The increase of seed vigor might be one of the important physiological reasons that ICE6 improved the germination and seedling growth.

Chlorophyll is an important biochemical characteristic of plant health [36]. We found seed treatment with ICE6 under proper conditions could improve the chlorophyll content of rice seedlings. Chlorophyll is the most widely distributed natural pigment of cyclic tetrapyrrole in nature, which is a kind of macrocyclic compounds derived from protoporphyrin IX via biosynthesis. It contains nearly 30 family members in nature with three different oxidation levels of carbon frame structure: porphyrin, chlorin and bacterochlorin [37]. Porphyrin is a kind of macrocyclic compounds with substituent groups on the porphyrin ring, and it can form stable metalloporphyrin complexes with metals. Metalloporphyrins have many applications, and play an important role in protecting the normal growth of biological organisms [38]. For example, iron porphyrins are efficient and highly selective catalysts [39,40]. Magnesium porphyrins play a key role in photosynthesis in plant cells [41]. Chlorin e6 is a hydrophilic photosensitizers with structure similar to porphyrin [42]. As the similar skeleton of chlorophyll a and b, increased chlorin e6 after ICE6 application might promote chlorophyll biosynthesis, or inhibit the degradation of chlorophyll by competitive binding with chlorophyll enzyme. Of course, the detailed molecular mechanisms remain to be further elucidated.

Iron has a fundamental role in photosynthesis, DNA and chlorophyll biosynthesis, mitochondrial respiration and nitrogen fixation. It has been suggested that iron is not directly involved in the chlorophyll biosynthesis, but it is required indirectly in the formation of chlorophyll precursor molecule, namely 5-aminolevulinic acid (ALA) [43]. The element is also a key constituent of many important proteins, such as ferredoxin, catalase, peroxidase and superoxide dismutase [44]. Therefore, iron is a limiting factor for plant biomass production and quality [45]. Seed treatment with nano-iron oxide enhances germination, seedling growth and salinity tolerance of sorghum [17]. It was considered that available iron supply from ICE6 might be an important reason for promoting rice seedlings growth.

In addition, we also found that ICE6 could improve the regeneration ability of rice seedlings. When part of the body is damaged or lost, many organisms can regenerate new tissues or organs to minimize the impact of local damage [46]. Regeneration is a physiological response widely preserved in animals and plants. Compared with animals, plants generally have a high degree of developmental plasticity, and show various types of tissue or organ regeneration [47]. When seeds were primed by ICE6, rice seedlings with lost buds could recover quickly and grow new buds, exhibiting strong regeneration ability, which was also a side evidence of the growth promoting effect of ICE6. The common plants with strong regeneration ability include lichen [48], soybean [49], Aster scaber [50], etc. Ratooning rice is a common cultivation mode in Sichuan, Chongqing, Hubei and Hunan provinces of the Yangtze River Basin in China. The finding suggested that ICE6 might have a potential application in the growth regulation of ratooning rice, of course, which requires further field trials to verify.

This study provided reliable data reference for the application of ICE6 in rice production. At present, the large-scale field efficacy evaluation of ICE6 on rice plants is in progress, and its effect of promoting growth and increasing yield needs to be further verified in practice, which is of great significance for the large-scale application of ICE6.

\section{Conclusions}

In this study, we evaluated the effect of seed soaking with ICE6 preparation on rice seed germination and seedling growth. Under the optimum soaking concentration (100-200 mg/L) and time (24-48 h), seed soaking with ICE6 could improve rice seed germination, promote seedling growth and increase the chlorophyll content in plants, exhibiting excellent growth promoting effect. After ICE6 priming, the increase of seed vigor might be an important physiological reason for its growth promoting effect. In addition, ICE6 treatment could also enhance the regeneration ability of seedlings. This work provided 
reliable reference data for the application of ICE6 in rice production, and it needs to further study the effect of this PGR on promoting rice growth under field conditions.

Author Contributions: Conceptualization, S.L. and L.W.; methodology, S.L. and Y.X.; formal analysis, S.L.; investigation, Y.X. and S.L.; writing—original draft, S.L. and Y.X.; writing—review and editing, S.L.; visualization, S.L.; supervision, Y.J.; project administration, L.W. and Y.J.; funding acquisition, Y.J. All authors have read and agreed to the published version of the manuscript.

Funding: This research was funded by the Jiangsu Agricultural Science and Technology Innovation Fund, grant number CX(21)1011.

Institutional Review Board Statement: Not applicable.

Informed Consent Statement: Not applicable.

Data Availability Statement: The data presented in this study are available on request from the corresponding authors.

Conflicts of Interest: The authors declare no conflict of interest.

\section{References}

1. He, P.; Shen, L.; Lu, C.; Chen, Y.; Zhu, L. Analysis of quantitative trait loci which contribute to anther culturability in rice (Oryza sativa L.). Mol. Breed. 1998, 4, 165-172. [CrossRef]

2. Bandumula, N. Rice production in Asia: Key to global food security. Proc. Natl. Acad. Sci. India Sect. B Biol. Sci. 2018, 88, 1323-1328. [CrossRef]

3. You, H.; Zhang, O.; Xu, L.; Liang, C.; Xiang, X. Effects of soluble starch synthase IIa allelic variation on rice grain quality with different Waxy backgrounds. J. Sci. Food Agric. 2020, 100, 5344-5351. [CrossRef]

4. Santner, A.; Calderon-Villalobos, L.I.; Estelle, M. Plant hormones are versatile chemical regulators of plant growth. Nat. Chem. Biol. 2009, 5, 301-307. [CrossRef] [PubMed]

5. Singh, M.; Bashri, G.; Prasad, S.M.; Singh, V.P. Kinetin alleviates UV-B-induced damage in Solanum lycopersicum: Implications of phenolics and antioxidants. J. Plant Growth Regul. 2019, 38, 831-841. [CrossRef]

6. Sun, S.; Zhou, X.; Cui, X.; Liu, C.; Fan, Y.; McBride, M.B.; Li, Y.; Li, Z.; Zhuang, P. Exogenous plant growth regulators improved phytoextraction efficiency by Amaranths hypochondriacus L. in cadmium contaminated soil. Plant Growth Regul. 2020, 90, 29-40. [CrossRef]

7. Rademacher, W. Plant growth regulators: Backgrounds and uses in plant production. J. Plant Growth Regul. 2015, 34, 845-872. [CrossRef]

8. Jiang, K.; Asami, T. Chemical regulators of plant hormones and their applications in basic research and agriculture. Biosci. Biotechnol. Biochem. 2018, 82, 1265-1300. [CrossRef]

9. Xu, X.; Hou, X.; Han, M.; Qiu, S.; Li, Y. Simultaneous determination of multiclass plant growth regulators in fruits using the quick, easy, cheap, effective, rugged, and safe method and ultra-high performance liquid chromatography-tandem mass spectrometry. $J$. Sep. Sci. 2020, 43, 788-798. [CrossRef] [PubMed]

10. Zanardo, D.I.L.; Lima, R.B.; Ferrarese, M.L.L.; Bubna, G.A.; Ferrarese-Filho, O. Soybean root growth inhibition and lignification induced by $p$-coumaric acid. Environ. Exp. Bot. 2008, 66, 25-30. [CrossRef]

11. Mathesius, U. Flavonoid functions in plants and their interactions with other organisms. Plants 2018, 7, 30. [CrossRef]

12. Vanholme, B.; El Houari, I.; Boerjan, W. Bioactivity: Phenylpropanoids' best kept secret. Curr. Opin. Biotechnol. 2019, 56, 156-162. [CrossRef]

13. Singh, G.; Sharma, G.; Sanchita; Kalra, P.; Batish, D.R.; Verma, V. Role of alkyl silatranes as plant growth regulators: Comparative substitution effect on root and shoot development of wheat and maize. J. Sci. Food Agric. 2018, 98, 5129-5133. [CrossRef] [PubMed]

14. Wang, Y.; Zhang, L.; Jiang, H.; Tong, M.; Ren, Y. Effects of iron chlorophyllin on wheat under different fertility conditions. Jiangsu Agric. Sci. 2012, 40, 78-79.

15. Xing, Y.; Chen, L.; Meng, D.; Xu, J.; Shi, J. Application effect of 0.02\% iron chlorin soluble powder in tobacco. Jiangsu Agric. Sci. 2020, 48, 91-94.

16. Xing, Y.; Chen, L.; Meng, D.; Xu, J.; Shi, J. Effect of a new plant growth regulator iron chlorin $0.02 \%$ soluble powder on the growth and yield of grape. Agrochemicals 2020, 59, 933-936.

17. Maswada, H.F.; Djanaguiraman, M.; Prasad, P.V. Seed treatment with nano-iron (III) oxide enhances germination, seeding growth and salinity tolerance of sorghum. J. Agron. Crop Sci. 2018, 204, 577-587. [CrossRef]

18. Fang, S.; Gao, K.; Hu, W.; Wang, S.; Chen, B.; Zhou, Z. Foliar and seed application of plant growth regulators affects cotton yield by altering leaf physiology and floral bud carbohydrate accumulation. Field Crops Res. 2019, 231, 105-114. [CrossRef]

19. Hou, G.; Liang, H.; Zhao, M.; Chen, C.; Meng, X.; Zhao, J.; Wu, Z. Effects of different treatments on seed germination of Bupleurum chinensis. J. Life Sci. 2018, 12, 129-133. 
20. Su, S.; Zhou, Y.; Qin, J.; Yao, W.; Ma, Z. Optimization of the method for chlorophyll extraction in aquatic plants. J. Freshw. Ecol. 2010, 25, 531-538. [CrossRef]

21. Ma, Z.; Liu, J.; Dong, J.; Yu, J.; Huang, S.; Lin, H.; Hu, S.; Wang, J. Optimized qualitative and quantitative methods for barley viability testing using triphenyl tetrazolium chloride staining. Cereal Chem. 2019, 96, 421-428. [CrossRef]

22. Xia, X.; Wang, Y.; Zhou, Y.; Tao, Y.; Mao, W.; Shi, K.; Asami, T.; Chen, Z.; Yu, J. Reactive oxygen species are involved in brassinosteroid-induced stress tolerance in cucumber. Plant Physiol. 2009, 150, 801-814. [CrossRef]

23. Harvey, B.M.; Oaks, A. Characteristics of an acid protease from maize endosperm. Plant Physiol. 1974, 53, 449-452. [CrossRef]

24. Ma, W.; Zhang, Z.; Zheng, Y.; Pan, W.; Qiu, T.; Guan, Y.; Hu, J. Determination of tobacco (Nicotiana tabacum) seed vigour using controlled deterioration followed by a conductivity test. Seed Sci. Technol. 2020, 48, 1-10. [CrossRef]

25. Lardon, R.; Geelen, D. Natural variation in plant pluripotency and regeneration. Plants 2020, 9, 1261. [CrossRef]

26. Bewley, J.D. Seed germination and dormancy. Plant Cell 1997, 9, 1055-1066. [CrossRef]

27. Finch-Savage, W.E.; Leubner-Metzger, G. Seed dormancy and the control of germination. New Phytol. 2006, 171, 501-523. [CrossRef] [PubMed]

28. Li, Q.; Zhou, Y.; Xiong, M.; Ren, X.; Han, L.; Wang, J.; Zhang, C.; Fan, X.; Liu, Q. Gibberellin recovers seed germination in rice with impaired brassinosteroid signalling. Plant Sci. 2020, 293, 110435. [CrossRef]

29. Paparella, S.; Araújo, S.S.; Rossi, G.; Wijayasinghe, M.; Carbonera, D.; Balestrazzi, A. Seed priming: State of the art and new perspectives. Plant Cell Rep. 2015, 34, 1281-1293. [CrossRef]

30. Chen, K.; Arora, R. Dynamics of the antioxidant system during seed osmopriming, post-priming germination, and seedling establishment in Spinach (Spinacia oleracea). Plant Sci. 2011, 180, 212-220. [CrossRef]

31. Wang, W.; Chen, Q.; Hussain, S.; Mei, J.; Dong, H.; Peng, S.; Huang, J.; Cui, K.; Nie, L. Pre-sowing seed treatments in direct-seeded early rice: Consequences for emergence, seedling growth and associated metabolic events under chilling stress. Sci. Rep. 2016, 6, 19637. [CrossRef] [PubMed]

32. Wen, D.; Hou, H.; Meng, A.; Meng, J.; Xie, L.; Zhang, C. Rapid evaluation of seed vigor by the absolute content of protein in seed within the same crop. Sci. Rep. 2018, 8, 5569. [CrossRef] [PubMed]

33. Damaris, R.N.; Lin, Z.; Yang, P.; He, D. The rice alpha-amylase, conserved regulator of seed maturation and germination. Int. J. Mol. Sci. 2019, 20, 450. [CrossRef] [PubMed]

34. Yamakawa, H.; Hirai-Kimura, R.; Nakata, Y.; Nakata, M.; Kuroda, M.; Yamaguchi, T. An activity-staining method on filtration paper enables high-throughput screening of temperature-sensitive and inactive mutations of rice $\alpha$-amylase for improvement of rice grain quality. Plant Cell Physiol. 2017, 58, 658-667. [CrossRef] [PubMed]

35. Li, C.; Cao, X.; Gu, Z.; Wen, H. A preliminary study of the protease activities in germinating brown rice (Oryza sativa L.). J. Sci. Food Agric. 2011, 91, 915-920. [CrossRef] [PubMed]

36. Xu, J.; Volk, T.A.; Quackenbush, L.J.; Stehman, S.V. Estimation of shrub willow leaf chlorophyll concentration across different growth stages using a hand-held chlorophyll meter to monitor plant health and production. Biomass Bioenergy 2021, 150, 106132. [CrossRef]

37. Tamiaki, H.; Fukai, K.; Shimazu, H.; Shoji, S. Synthesis of zinc chlorophyll homo/hetero-dyads and their folded conformers with porphyrin, chlorin, and bacteriochlorin $\pi$-systems. Photochem. Photobiol. 2014, 90, 121-128. [CrossRef]

38. Chen, J.; Zhu, Y.; Kaskel, S. Porphyrin-based metal-organic frameworks for biomedical applications. Angew. Chem. Int. Edit. 2021 60, 5010-5035. [CrossRef] [PubMed]

39. Lee, J.H.; Park, J. A manganese porphyrin complex is a novel radiation protector. Free Radical Biol. Med. 2004, $37,272-283$. [CrossRef]

40. Sun, W.; Kühn, F.E. Efficient aldehyde olefination reactions catalyzed by an iron porphyrin complex in an ionic liquid. Tetrahedron Lett. 2005, 45, 7415-7418. [CrossRef]

41. Borah, K.D.; Bhuyan, J. Magnesium porphyrins with relevance to chlorophylls. Dalton Trans. 2017, 46, 6497-6509. [CrossRef]

42. Mojzisova, H.; Bonneau, S.; Vever-Bizet, C.; Brault, D. Cellular uptake and subcellular distribution of chlorin e6 as functions of pH and interactions with membranes and lipoproteins. Biochim. Biophys. Acta Biomembr. 2007, 1768, 2748-2756. [CrossRef] [PubMed]

43. Martin, M.H.; Marschner, H. Mineral nutrition of higher plants. J. Ecol. 1988, 76, 1250. [CrossRef]

44. Nagajyoti, P.C.; Lee, K.D.; Sreekanth, T.V. Heavy metals, occurrence and toxicity for plants: A review. Environ. Chem. Lett. 2010, 8, 199-216. [CrossRef]

45. Briat, J.F.; Dubos, C.; Gaymard, F. Iron nutrition, biomass production, and plant product quality. Trends Plant Sci. 2015, 20, 33-40. [CrossRef] [PubMed]

46. Ikeuchi, M.; Ogawa, Y.; Iwase, A.; Sugimoto, K. Plant regeneration: Cellular origins and molecular mechanisms. Development 2016, 143, 1442-1451. [CrossRef]

47. Pulianmackal, A.J.; Kareem, A.V.; Durgaprasad, K.; Trivedi, Z.B.; Prasad, K. Competence and regulatory interactions during regeneration in plants. Front. Plant Sci. 2014, 5, 142. [CrossRef] [PubMed]

48. Nishihama, R.; Ishizaki, K.; Hosaka, M.; Matsuda, Y.; Kubota, A.; Kohchi, T. Phytochrome-mediated regulation of cell division and growth during regeneration and sporeling development in the liverwort Marchantia polymorpha. J. Plant Res. 2015, 128, 407-421. [CrossRef] 
49. Raza, G.; Singh, M.B.; Bhalla, P.L. In vitro plant regeneration from commercial cultivars of soybean. BioMed Res. Int. 2017, 2017, 7379693. [CrossRef]

50. Boo, K.H.; Cao, D.V.; Pamplona, R.S.; Lee, D.; Riu, K.; Lee, D. In vitro plant regeneration of Aster scaber via somatic embryogenesis. Biosci. Biotech. Bioch. 2015, 79, 725-731. [CrossRef] 